\title{
Genetic Variability and Molecular Diversity Analysis in Turmeric (Curcuma longa L.)
}

\author{
Priya Patel, R.K. Patel, K.G. Modha, Thokchom Joydeep Singh, Manju Singh
}

10.18805/IJARe.A-5800

\begin{abstract}
Background: Turmeric is an age old herbaceous plant belonging to the family Zingiberaceae growing in Tropical Africa and India with huge national and international demands. Conventionally, turmeric accessions are characterized using morphological and agronomical traits but less work is done in molecular characterization which is needed for thorough trait identification.

Methods: The investigation was carried out during Kharif 2016-17 and comprised of thirty diverse genotypes of turmeric analyzed for genetic variability and molecular diversity which were evaluated in randomized block design with two replications. Fresh tender leaves were used to isolate DNA and PCR was performed with 9 SSR markers.

Result: The values of phenotypic coefficient of variation were slightly higher than genotypic coefficient of variation. Highest heritability was observed for days to maturity, genetic advance was observed highest for green rhizome yield. Out of 9 SSR markers, primer pair $5,6,7,8$ and 9 were reported to exhibit $100 \%$ polymorphism, whereas; in terms of PIC, primer pairs 6 and 9 were found to be highly efficient ones. The similarity coefficient ranged from 0.44 to 1.00 and dendogram categorized the 30 genotypes into two main clusters.

Key words: Dendogram, Jaccard's similarity coefficient, Polymorphism information content.
\end{abstract}

\section{INTRODUCTION}

Turmeric (Curcuma longa L.) is an age old herbaceous plant belonging to the family Zingiberaceae and popularly known as "Indian saffron". It is a native to South East Asia Turmeric is famous with human civilization, religion and customs. India has achieved a predominant position as a largest producer of turmeric in the world. Besides India, it is also grown in China, Taiwan, Indonesia, Sri Lanka, Thailand and other tropical countries. Among them, highest diversity is concentrated in India and Thailand (Hikmat et al. 2011). Turmeric is a cross-pollinated, triploid species $(2 n=3 x=63)$, which can be vegetatively propagated using its underground rhizomes (Sasikumar, 2005). A report based on the flow cytometric data and chromosome counts suggested a new ploidy status [9x] to turmeric by defining a new basic chromosome number $[x=7]$ but without contradicting the triploid status (Skornickova et al. 2007).

Even though germplasm collections represent the main source of variability for turmeric genetic improvement, studies aimed at characterizing these collections are scarce and mostly restricted to the phenotypic evaluation of accessions from India, which is the major turmeric grower of the world. Conventional taxonomic techniques in conjunction with molecular biology tools may go a long way in resolving the taxonomic confusion prevailing in the genus. Hence, the experiment was designed to study the genetic variability, molecular diversity and characterization of the turmeric genotypes present in 30 turmeric germplasm collected from various geographies for 14 quantitative traits

\section{MATERIALS AND METHODS Experimental material}

The investigation was carried out during Kharif 2016-17 at
Department of Genetics and Plant Breeding, N.M. College of Agriculture, Navsari Agricultural University, Navsari-396 450, Gujarat, India.

Corresponding Author: Priya Patel, Department of Genetics and Plant Breeding, N.M. College of Agriculture, Navsari Agricultural University, Navsari-396 450, Gujarat, India.

Email: 1995priyapatel@gmail.com

How to cite this article: Patel, P., Patel, R.K., Modha, K.G., Singh, T.J., Singh, M. (2021). Genetic Variability and Molecular Diversity Analysis in Turmeric (Curcuma longa L.). Indian Journal of Agricultural Research. DOI: 10.18805/IJARe.A-5800.

Submitted: 21-04-2021 Accepted: 30-09-2021 Online: 16-11-2021

the Department of Genetics and Plant Breeding, N.M. College of Agriculture, Navsari Agricultural University, Navsari. Thirty different genotypes were grown in randomized block design in two replications. Each plot consisted of twenty plants in a row at $45 \times 30 \mathrm{~cm}^{2}$ inter and intra row spacing. All the recommended package of practices were adopted for raising a successful and healthy crop. The genotypes utilized are listed in Table 1. The data were recorded from five randomly selected plants for each genotype in both the replications for fourteen different characters, viz., plant height $(\mathrm{cm})$, leaf length $(\mathrm{cm})$, leaf width (cm), tillers per plant, mother rhizomes per plant, primary fingers per rhizome, secondary fingers per rhizome, rhizome length $(\mathrm{cm})$, rhizome width $(\mathrm{cm})$, green rhizome weight $(\mathrm{kg})$, dry rhizome weight recovery (\%), powder recovery (\%), green rhizome yield (t/ha) and days to maturity.

\section{DNA isolation}

Total genomic DNA was extracted from the fresh leaves of 60 days old plants by using CetylTrimethyl Ammonium 
Bromide (CTAB) method with some modifications. The integrity of DNA was judged on $0.8 \%$ agarose gel by electrophoresis. Spectro photometry was performed to determine DNA concentration by using Nano-Drop N.D.1000 (Software V.3.3.2, Thermo Scientific, U.S.A.). The absorbance at $260 \mathrm{~nm}$ and $280 \mathrm{~nm}$ was measured and concentration of DNA was obtained. The values of purity and concentration of DNA of 30 turmeric cultivars are shown in Table 1. Dilutions of $50 \mathrm{ng} / \mu \mathrm{L}$ working solutions were prepared from stock solutions for PCR.

\section{PCR and polymorphism data analysis}

The PCR reactions for SSR were carried out according to method given by Yadav et al. (2007) with some modifications. Pair wise comparison of genotypes, based on the presence (1) or absence (0) of unique and shared polymorphic products was used to generate Jaccard's similarity coefficient by NT-SYS-pc version 2.02e software. The similarity coefficient was used to construct a dendrogram by the unweighted pair group method with arithmetic

Table 1: List of turmeric genotypes, DNA absorbance ratio and DNA concentration.

\begin{tabular}{|c|c|c|c|}
\hline Genotype & Source & $\begin{array}{l}\text { Absorbance } \\
A_{260} / A_{280} \text { ratio }\end{array}$ & $\begin{array}{c}\text { Concentration } \\
\mathrm{ng} / \mu \mathrm{l}\end{array}$ \\
\hline NVST-1 & NAU, Navsari & 1.98 & 209.1 \\
\hline NVST-2 & NAU, Navsari & 1.89 & 189.3 \\
\hline NVST-4 & NAU, Navsari & 2.10 & 225.5 \\
\hline NVST-5 & NAU, Navsari & 1.99 & 114.5 \\
\hline NVST-6 & NAU, Navsari & 1.96 & 148.3 \\
\hline NVST-7 & NAU, Navsari & 1.87 & 122.3 \\
\hline NVST-11 & NAU, Navsari & 2.03 & 163.6 \\
\hline NVST-12 & NAU, Navsari & 1.89 & 187.7 \\
\hline NVST-13 & NAU, Navsari & 1.90 & 144.3 \\
\hline NVST-15 & NAU, Navsari & 2.22 & 199.0 \\
\hline NVST-17 & NAU, Navsari & 1.97 & 141.0 \\
\hline NVST-20 & NAU, Navsari & 1.90 & 192.0 \\
\hline NVST-21 & NAU, Navsari & 1.96 & 94.9 \\
\hline NVST-23 & NAU, Navsari & 2.29 & 167.7 \\
\hline NVST-24 & NAU, Navsari & 1.98 & 100.5 \\
\hline NVST-25 & NAU, Navsari & 2.16 & 298.6 \\
\hline NVST-27 & NAU, Navsari & 2.29 & 290.3 \\
\hline NVST-29 & NAU, Navsari & 1.88 & 258.4 \\
\hline NVST-31 & NAU, Navsari & 2.13 & 223.8 \\
\hline NVST-33 & NAU, Navsari & 1.90 & 288.7 \\
\hline NVST-34 & NAU, Navsari & 2.26 & 163.6 \\
\hline NVST-38 & NAU, Navsari & 2.21 & 224.2 \\
\hline NVST-86 & NAU, Navsari & 1.99 & 98.6 \\
\hline NVST-88 & NAU, Navsari & 2.19 & 465.4 \\
\hline NVST-91 & NAU, Navsari & 2.00 & 331.8 \\
\hline NVST-96 & NAU, Navsari & 1.95 & 237.5 \\
\hline GNT-1 & NAU, Navsari & 1.89 & 387.9 \\
\hline GNT-2 & NAU, Navsari & 1.93 & 69.3 \\
\hline SUGANDHAM & GAU, Jagudan & 2.00 & 176.7 \\
\hline PRATIBHA & IISR, Calicut & 2.10 & 291.8 \\
\hline
\end{tabular}

averages (UPGMA). A combined analysis was performed by using dendrogram along with Jaccard's similarity coefficient matrix.

\section{Statistical analysis}

Average value of data from these plants was computed and used for statistical analysis. Mean values of different characters were subjected to statistical analysis. The data recorded for different characters was subjected to analysis of variance with the formula suggested by Panse and Sukhatme (1978). Phenotypic and genotypic components of variance were estimated by applying the formula suggested by Cochran and Cox (1959). Phenotypic and genotypic co-efficient of variation were calculated by using the formulae suggested by Cockerham (1963). Heritability was estimated with the formula given by Allard (1960). Genetic advance for each character was predicted by the formula given by Johnson et al. (1955).

\section{RESULTS AND DISCUSSION}

The present experimental material exhibited a wide range of variation by virtue of showing significant genotypic differences for all the traits viz., leaf length, leaf width, plant height, tillers per plant, days to maturity, rhizome length, rhizome width, rhizome weight, primary fingers per rhizome, secondary fingers per rhizome, mother rhizomes per plant, green rhizome yield, dry rhizome weight recovery and powder recovery (Table 2). This suggests that there is an ample scope for identification of genotypes with high yield, early maturity and better processing quality traits. Similar results for most of the characters were reported by Chattopadhyay et al. (2004) and Singh et al. (2012). There was a close correspondence between genotypic and phenotypic variance. This implied that phenotypic variability may be considered as a reliable measure of genotypic variability. Phenotypic and genotypic variances were greater than environmental variances for most of the characters except leaf width, mother rhizomes per plant, secondary fingers per rhizome and powder recovery (Table 3), which indicates that influence of environmental factors on expression of these traits were lower or negligible.

The estimates of genotypic (GCV) and phenotypic (PCV) coefficients of variation indicated that the values of PCV were higher than GCV due to interaction of the genotypes with the environment or other environmental factors influencing the expression of these characters (Table 4). Higher GCV was observed for dry rhizome weight recovery followed by green rhizome weight, green rhizome yield, primary fingers per rhizome, mother rhizomes per plant and secondary fingers per rhizome. High PCV was observed in green rhizome weight, green rhizome yield and primary fingers per rhizome. The results indicated the presence of wide variation for these characters pointing out the scope for improvement through simple selection. Similarly, tillers per plant, rhizome length, rhizome width, leaf length, leaf 
width and plant height had moderate, while powder recovery and days to maturity exhibited very low coefficients of variation.

It is not possible to determine the amount of variability, which is heritable with the help of genotypic coefficient of variation alone. Burton (1952) suggested that GCV together with a heritability estimate would provide better idea of the amount of genetic gain expected through phenotypic selection. The estimates of heritability were observed to be high for days to maturity followed by dry rhizome weight recovery, rhizome length, primary fingers per rhizome, green rhizome yield, rhizome weight and leaf width indicating that these characters are less influenced by the environmental fluctuations. Moderate heritability was observed for tillers per plant, plant height, leaf length, mother rhizomes per plant, secondary fingers per rhizome, leaf width and powder recovery indicating more environmental influence on such traits. The highest moderate genetic advance was observed for plant height followed by days to maturity and green rhizome yield, while low values of genetic advance was recorded for remaining characters (Table 4).

Genetic advance is the deviation between mean values of the progeny from selected individuals and base population. Higher genetic advance over base population mean anticipates improvement under selection. Genetic

Table 2: Analysis of variance for various traits in turmeric.

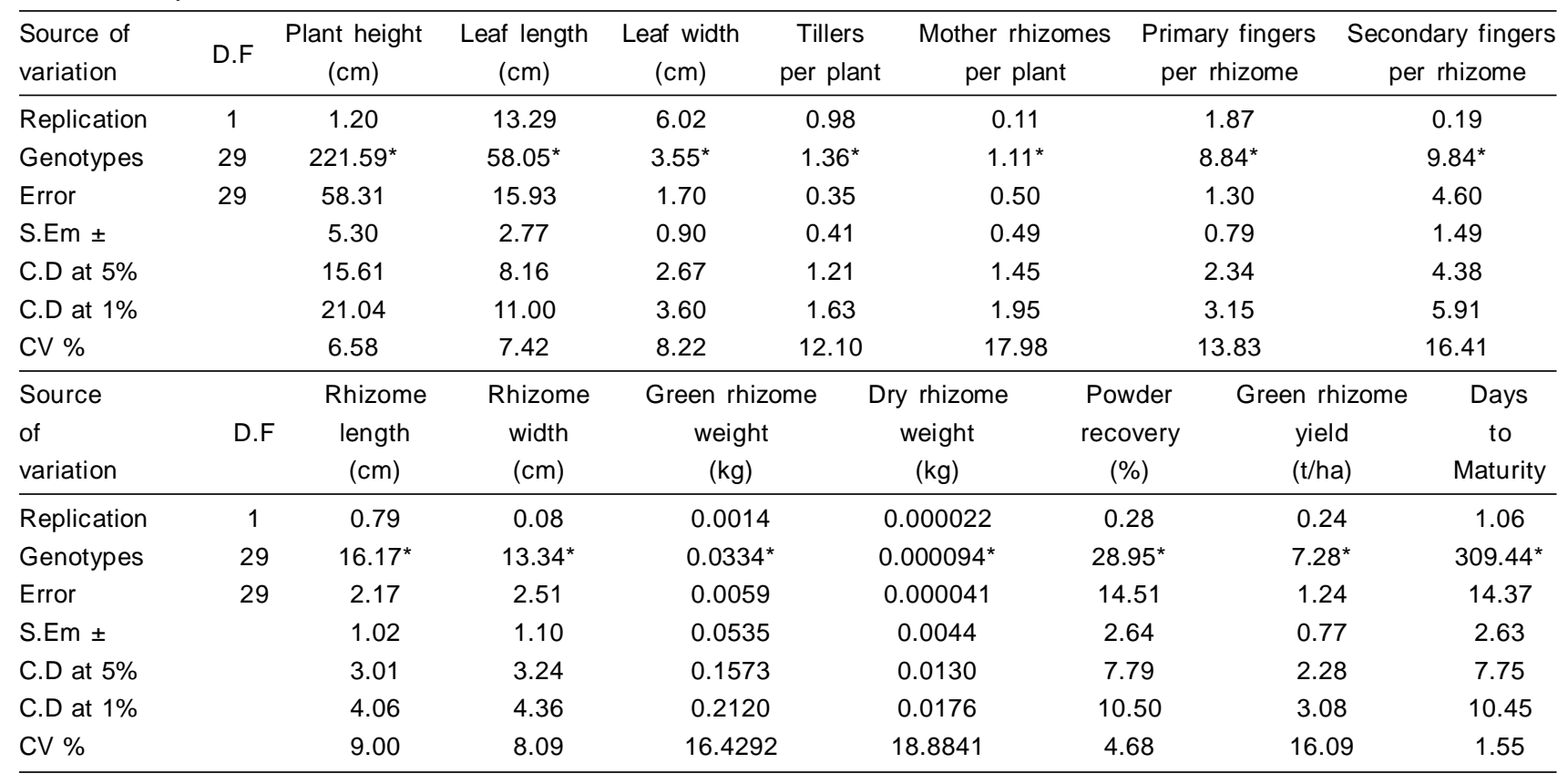

Table 3: Estimates of range, mean and components of variance for fourteen different characters of turmeric.

\begin{tabular}{|c|c|c|c|c|c|}
\hline \multirow{2}{*}{ Characters } & \multirow{2}{*}{ Range } & \multirow{2}{*}{ Mean $\pm S E(m)$} & \multicolumn{3}{|c|}{ Components of variance } \\
\hline & & & $\mathrm{P}$ & $\mathrm{G}$ & $\mathrm{E}$ \\
\hline Plant height (cm) & $92.50-134.50$ & $115.9450 \pm 5.3999$ & 139.95 & 81.64 & 58.31 \\
\hline Leaf length $(\mathrm{cm})$ & $42.55-68.50$ & $53.7707 \pm 2.8229$ & 36.99 & 21.05 & 15.93 \\
\hline Leaf width $(\mathrm{cm})$ & $12.15-18.17$ & $15.8898 \pm 0.9242$ & 2.63 & 0.92 & 1.70 \\
\hline Tillers per plant & $3.60-7.00$ & $4.8883 \pm 0.4185$ & 0.85 & 0.50 & 0.35 \\
\hline Mother rhizome per plant & $2.50-6.00$ & $3.9433 \pm 0.5015$ & 0.80 & 0.30 & 0.50 \\
\hline Primary fingers per rhizome & $4.00-12.50$ & $8.2700 \pm 0.8093$ & 5.07 & 3.76 & 1.30 \\
\hline Secondary fingers per rhizome & $9.50-18.00$ & $13.0700 \pm 1.5172$ & 7.22 & 2.61 & 4.60 \\
\hline Rhizome length $(\mathrm{cm})$ & $11.45-23.40$ & $16.3828 \pm 1.0435$ & 9.17 & 6.99 & 2.17 \\
\hline Rhizome width $(\mathrm{cm})$ & $13.00-23.90$ & $19.5867 \pm 1.1209$ & 7.92 & 5.41 & 2.51 \\
\hline Rhizome weight (kg) & $0.2170-0.8230$ & $0.4682 \pm 0.0544$ & 0.01 & 0.01 & 0.00 \\
\hline Dry rhizome weight recovery (\%) & 4.1214-11.9923 & $7.3541 \pm 0.6976$ & 5.91 & 4.93 & 0.97 \\
\hline Powder recovery (\%) & $74.3350-90.60$ & $81.3805 \pm 2.6940$ & 21.73 & 7.22 & 14.51 \\
\hline Green rhizome yield (t/ha) & $3.2149-12.1926$ & $6.9456 \pm 0.7905$ & 4.26 & 3.01 & 1.24 \\
\hline Days to maturity & $227.50-271.00$ & $244.6333 \pm 2.6811$ & 161.91 & 147.53 & 14.37 \\
\hline
\end{tabular}

${ }^{*} \mathrm{P}=$ Phenotypic variance, ${ }^{*} \mathrm{G}=$ Genotypic variance, ${ }^{*} \mathrm{E}=$ Environmental variance. 
advance expressed as per cent of mean was recorded high for dry rhizome weight recovery, days to maturity, green rhizome weight, primary fingers per rhizome, rhizome length, tillers per plant and rhizome width. It was recorded moderate for mother rhizomes per plant, secondary fingers per rhizome, leaf length and plant height. However, it was recorded low for days to maturity, leaf width and powder recovery (Table 4).

Heritability indicates the effectiveness with which selection of a genotype can be based on phenotypic performance, but fails to indicate the genetic progress and nature of gene action. Heritability estimates along with genetic gains are more effective and reliable in predicting the improvement through selection (Johnson et al. 1955). In present investigation, high heritability coupled with high genetic advance expressed as per cent of mean was found for primary fingers per rhizome, rhizome length, rhizome width, green rhizome weight, dry rhizome weight and days to maturity which indicates that these characters are governed by additive gene action. Hence, improvement for these traits through direct selection would be possible. High value of heritability associated with low genetic advance as

Table 4: Estimates of genotypic and phenotypic coefficients of variation, heritability, genetic advance and genetic advance as per cent of mean for fourteen different characters of turmeric.

\begin{tabular}{lccccc}
\hline Characters & $\begin{array}{c}\text { PCV } \\
(\%)\end{array}$ & $\begin{array}{c}\text { GCV } \\
(\%)\end{array}$ & $\begin{array}{c}\text { Heritability } \\
\text { (Broad sense \%) }\end{array}$ & $\begin{array}{c}\text { Genetic } \\
\text { advance }\end{array}$ & $\begin{array}{c}\text { Genetic advance } \\
\text { (as \% of mean) }\end{array}$ \\
\hline Plant height (cm) & 10.2035 & 7.7929 & 58.33 & 14.2159 & 12.2609 \\
Leaf length (cm) & 11.3116 & 8.5339 & 56.92 & 7.1316 & 13.2631 \\
Leaf width (cm) & 10.2100 & 6.0483 & 35.09 & 1.1728 & 7.3808 \\
Tillers per plant & 18.9240 & 14.5448 & 59.07 & 1.1257 & 23.0286 \\
Mother rhizome per plant & 22.8123 & 14.0328 & 37.84 & 0.7012 & 17.7822 \\
Primary fingers per rhizome & 27.2442 & 23.4674 & 74.20 & 3.4437 & 41.6412 \\
Secondary fingers per rhizome & 20.5623 & 12.3819 & 36.26 & 2.0075 & 15.3592 \\
Rhizome length (cm) & 18.4890 & 16.1462 & 76.26 & 4.7586 & 29.0465 \\
Rhizome width (cm) & 14.3751 & 11.8802 & 68.30 & 3.9615 & 20.2257 \\
Rhizome weight (kg) & 29.9663 & 25.0612 & 69.94 & 0.2022 & 43.1754 \\
Dry rhizome weight recovery (\%) & 33.0619 & 30.2182 & 83.54 & 4.1841 & 56.8953 \\
Powder recovery (\%) & 5.7289 & 3.3019 & 33.22 & 3.1905 & 3.9204 \\
Green rhizome yield (t/ha) & 29.7429 & 25.0115 & 70.72 & 3.0094 & 43.3277 \\
Days to maturity & 5.2014 & 4.9651 & 91.12 & 23.8848 & 9.7635 \\
\hline
\end{tabular}

${ }^{*} \mathrm{PCV}=$ Phenotypic coefficient of variation ${ }^{*} \mathrm{GCV}=$ Genotypic coefficient of variation.

Table 5: Polymorphism information content (PIC) of SSR loci across various genotypes of turmeric.

\begin{tabular}{|c|c|c|c|c|c|c|}
\hline $\begin{array}{l}\text { Primer } \\
\text { pair }\end{array}$ & Sequence $\left(5^{\prime}-3^{\prime}\right)$ & $\begin{array}{l}\text { Total number } \\
\text { of bands } \\
\text { (a) }\end{array}$ & $\begin{array}{c}\text { Total number of } \\
\text { polymorphic } \\
\text { bands (b) }\end{array}$ & $\begin{array}{l}\text { Monomorphic } \\
\text { bands }\end{array}$ & $\begin{array}{l}\text { Polymorphism \% } \\
\qquad(\mathrm{b} / \mathrm{a} \times 100)\end{array}$ & $\begin{array}{l}\text { PIC } \\
\text { value }\end{array}$ \\
\hline Primer pair & CATGCAAATGGAAATTGACAC (F) & 3 & 2 & 1 & 66.66 & 0.41 \\
\hline 1 & TGATAAATTGACACATGGCAGTC (R) & & & & & \\
\hline Primer pair & TCATTAAAGTCCGATGGAA (F) & 2 & 1 & 1 & 50 & 0.48 \\
\hline 2 & TTCGATGCAGAAGGAG (R) & & & & & \\
\hline Primer pair & TTCAАСTTCTCСTCGCTC (F) & 2 & 0 & 2 & 0 & 0.33 \\
\hline 3 & GCAAGGTCTGCATCTATT (R) & & & & & \\
\hline Primer pair & AAACCGCAAGAAAACTGA (F) & 1 & 0 & 1 & 0 & 0 \\
\hline 4 & CTCTTGCCTGAACGATTCC (R) & & & & & \\
\hline Primer pair & ATGTGGTTGAGGAATGAT (F) & 2 & 2 & 0 & 100 & 0.09 \\
\hline 5 & CTATTTCCCATAGCCCTT (R) & & & & & \\
\hline Primer pair & GTTCACAGCTTTAGCAGGGACAA & 2 & 2 & 0 & 100 & 0.61 \\
\hline 6 & (F) СТССТСТССАТАТТСТССАТСТСG (R) & & & & & \\
\hline Primer pair & TTGCCAGTGTGCTTGTTCTC (F) & 2 & 2 & 0 & 100 & 0.52 \\
\hline 7 & TTGAAGGGAACACTGAAGGG (R) & & & & & \\
\hline Primer pair & CCGGTGAGGGTGATATCTTG & 1 & 1 & 0 & 100 & 0.12 \\
\hline 8 & (F) AAGCTCAAGCTCAAGCCAAT (R) & & & & & \\
\hline Primer pair & GGAGGAGGCAGTTGATTTGT (F) & 2 & 2 & 0 & 100 & 0.60 \\
\hline 9 & GCTTTGGTGGCTAGAGATGC (R) & & & & & \\
\hline
\end{tabular}


per cent of mean was found for green rhizome yield suggesting the importance of non-additive gene action in the expression of this trait. Characters like plant height, leaf length, mother rhizomes per plant and secondary fingers per rhizome showed moderate heritability coupled with moderate genetic advance which indicated presence of both additive and non-additive gene actions in expression of those traits, simple selection would be fairly rewarding for improvement of these traits. Moderate heritability coupled with low genetic advance was observed for the characters viz., leaf width and powder recovery which indicated that the characters were highly influenced by environmental effects and selection would be ineffective (Table 4).

Microsatellite or simple sequence repeat (SSR) constitutes a robust set of molecular markers widely used for population genetics studies, germplasm characterization, parentage analysis and marker-assisted selection in plants. During the span of experimentation, only 17 EST-SSR and 35 genomic SSR markers had been reported in turmeric. This limited availability arose the need to expand the then existing repertoire of microsatellite markers for future studies aiming at better estimation of genetic variability for the effective conservation of the genetic resources of turmeric (Senan et al.2013). SSR markers were utilized in the present study due to the fact that they are highly reproducible, abundantly distributed in eukryotic genomes, highly stringent and hypervariable.

Nine SSRs were utilized to characterize the genotypes, out of which, seven SSR markers resulted into polymorphism with banding pattern ranging from 1 to a maximum of 2 alleles per individual in all the loci. Two identified SSR markers were highly informative for genetic studies and are extremely useful in detecting the polymorphism at a specific locus in turmeric.

According to Akkaya and Bal (2004), high PIC value can be attributed to the use of more informative markers. Highest PIC value of 0.61 was observed for SSR primer pair 6 (Table 5). PIC value is reflection of allele diversity and frequency among the genotypes. The markers showed an average PIC of 0.60 , which confirms that SSR markers used in this study were highly informative because markers with PIC values of 0.56 or higher are highly informative for genetic studies and are extremely useful in distinguishing the polymorphism of a specific locus. The SSR polymorphism observed in the present study indicated that the genotypes were more diverse due to differences in origin, ecotype and speciation.

Similarity coefficient revealed a high level of similarity between many genotypes. Identical DNA fingerprints were observed among some genotypes, as only small portion of genome was captured due to the less number of markers utilized. Very low level of similarity was observed between the genotypes NVST-7 and NVST-4 (Table 6). Such kind of variation results from evolutionary phenomena like high mutation rate, replication slippage and unequal crossing over.

UPGMA cluster analysis grouped the genotypes into separate clusters and sub-clusters (Fig 1). Primer pairs 6 and 9 generated higher levels of polymorphism and these could be used to differentiate turmeric genotypes. Singh et al. (2015) obtained two major distinct clusters in dendrogram, which showed a significant genetic variation ranging between 0.60 and 0.98 among 10 turmeric genotypes using SSR primers. These SSR primers may be utilized for varietal identification and genetic diversity analysis in turmeric.

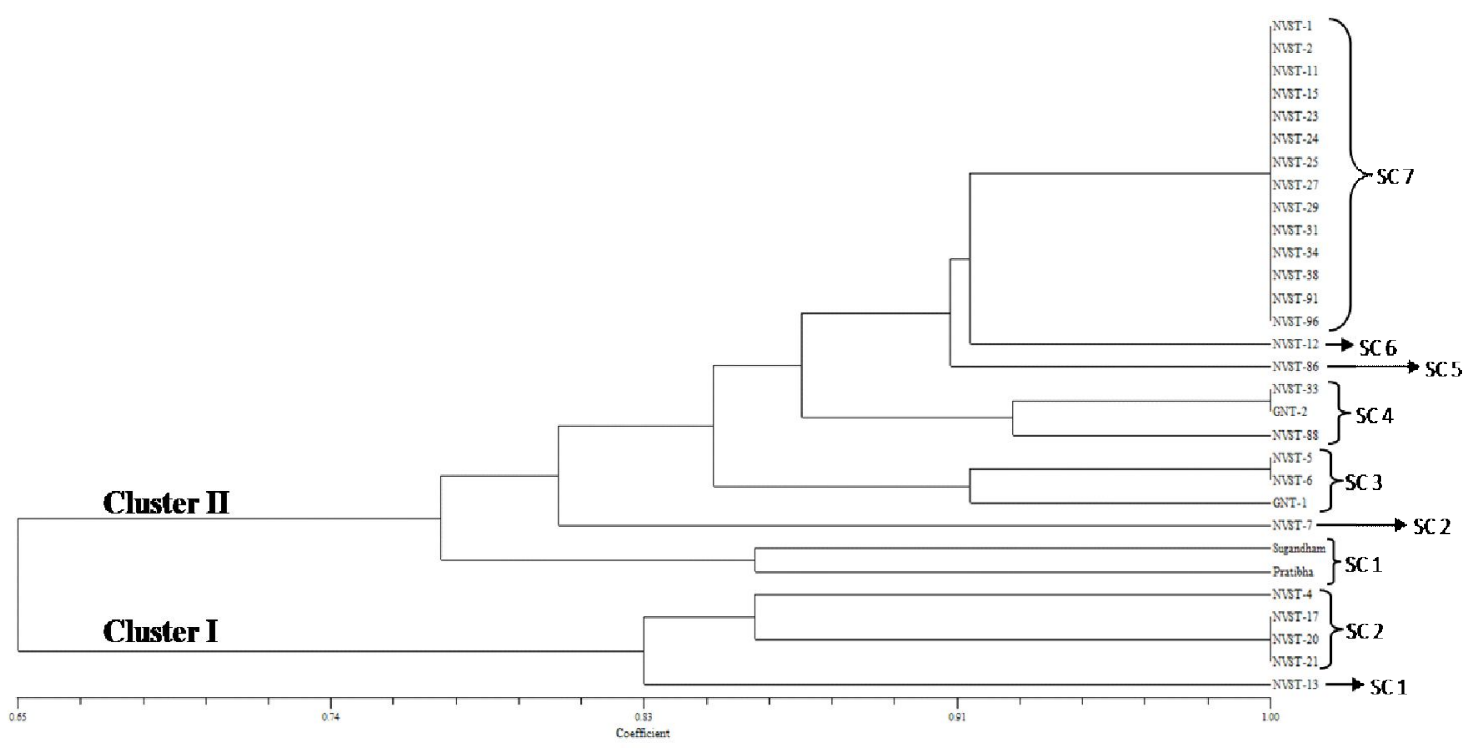

Fig 1: UPGMA Dendrogram showing clustering of 30 genotypes of turmeric based on SSR data. 


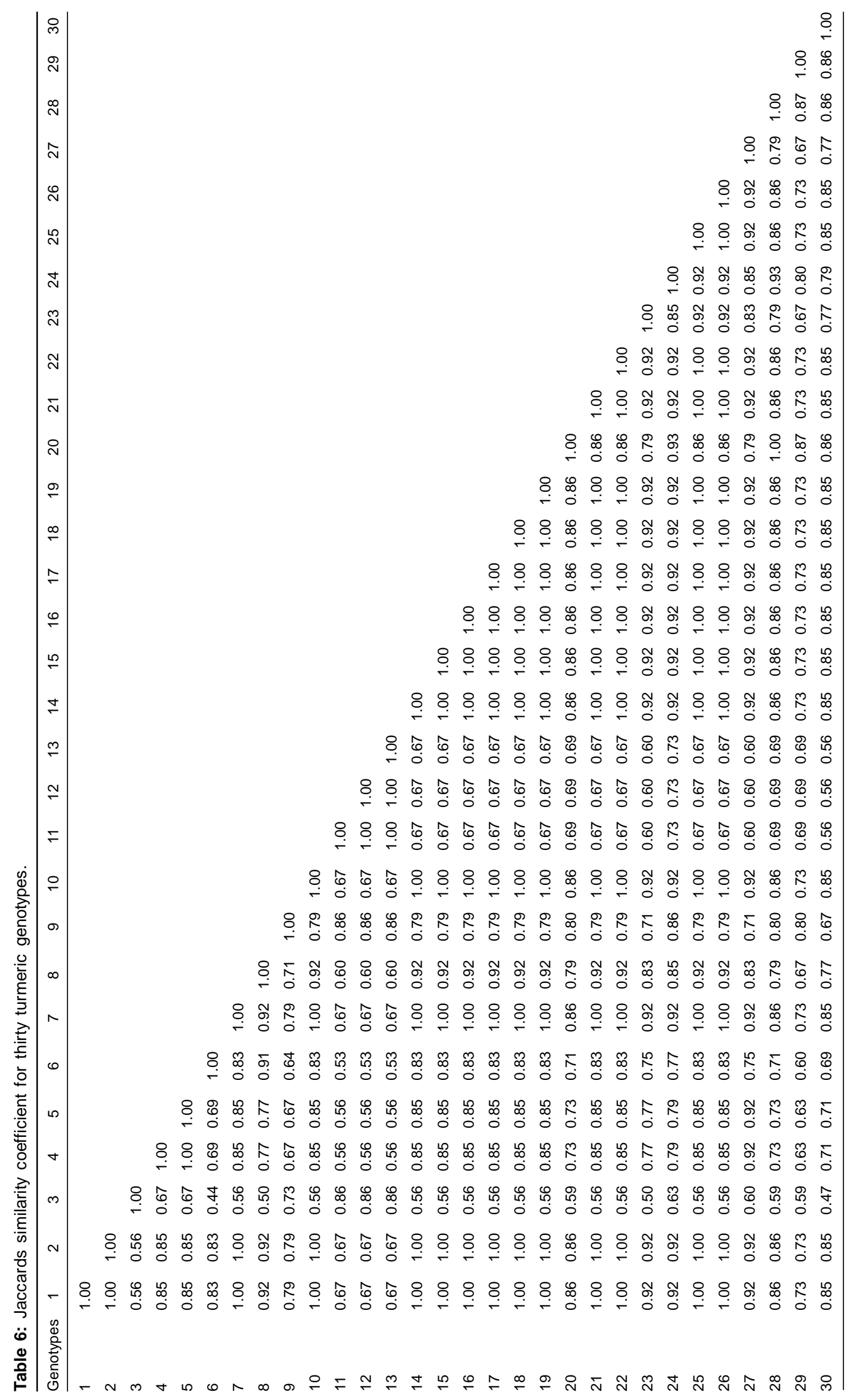




\section{CONCLUSION}

It can be concluded through the studies on variability, correlation, path coefficients and molecular diversity that plant height, tillers per plant, secondary fingers per rhizome, rhizome width, green rhizome weight, dry rhizome weight recovery and powder recovery are the most important contributing traits for improvement of green rhizome yield, therefore, these traits must be considered while establishing selection criteria for improvement of green rhizome yield in turmeric.

The experimentation of morphological diversity coupled with molecular diversity will increase the efficiency not only of varietal identification but also for genetic fingerprinting and clonal selection. Whole genome or transcriptome sequencing may be utilized to identify SSR polymorphisms at wider scale. This would further strengthen and enhance the improvement in turmeric in various breeding programmes.

\section{ACKNOWLEDGEMENT}

We are grateful to the Department of Genetics and Plant Breeding, N.M. College of Agriculture, N.A.U., Navsari for all resources and support provided during the experimentation.

\section{REFERENCES}

Akkaya, M.S. and Bal, E.B. (2004). Assessment of genetic variation of bread wheat varieties using microsatellite markers. Euphytica. 135: 179-185.

Allard, R.W. (1960). Principles of Plant Breeding. John Wiley and Sons, New York, 485.

Burton, G.W. (1952). Quantitative Inheritance in Grasses. Proceedings of $6^{\text {th }}$ International Grassland Congress. 1: 227-238.

Chattopadhyay, N., Hore, J.K. and Bandyopadhyay (2004). A studies on character association and genetic variability in turmeric. Horticultural Journal. 17: 259-266.
Cochran, W. and Cox, G.M. (1959). Experimental Designs, Asia Publishing House, Bombay. 293-304.

Cockerham, C.C. (1963). Estimation of Genetic Variance in Statistical Genetics and Plant Breeding, National Research Council, Washington DC. 53-94.

Hikmat, U.J., Malik, A.R. and Khan, Z.S. (2011). Assessment of genetic diversity of indigenous turmeric (Curcuma longa L.) germplasm from Pakistan using RAPD markers. Journal of Medicinal Plants Research. 5: 823-830.

Johanson, H.W., Robinson, H.F. and Comstock, R.E. (1955). Estimates of genetic and environmental variability in soybean. Agronomy Journal. 47: 314-318.

Panse, V.G. and Sukhatme, P.V. (1978). Statistical Methods for Agricultural Workers. ICAR, New Delhi. 103-108.

Sasikumar, B. (2005). Genetic resources of Curcuma diversity, characterization and utilisation. Plant Genetic Resources. 3: $230-251$

Senan, S., Kizhakayil, D., Sheeja, T.E., Sasikumar, B., Bhat, A.I. and Parthasarathy, V.A. (2013). Novel polymorphic microsatellite markers from turmeric, Curcuma longa $\mathrm{L}$. (Zingiberaceae). Acta Botanica Croatica. 72: 407-412.

Singh, A.K., Nanda, P., Singh, A. and Singh, B. (2015). Genetic diversity analysis in turmeric (Curcuma longa L.) based on SSR Markers. Journal of Biological Engineering Research and Review. 2: 20-24.

Singh, A.P., Pandey, V.P., Rahman, S.M.A. and Pervez, R. (2012). Genetic variability and character association in turmeric (Curcuma longa L.). Trends in Biosciences. 5: 11-13.

Skornickova, J.L., Sida, O., Jarolimova, V., Sabu, M., Fer, T., Travnicek, P. and Suda, J. (2007). Chromosome numbers and genome size variation in Indian species of curcuma (Zingiberaceae). Annals of Botany. 100: 505-526.

Yadav, O.P., Mitchell, S.E. and Zamora, A. (2007). Development of new simple sequence repeats markers for pearl millet. SAT e Journal. 3. 